\title{
Caracterização patogênica e molecular de Plasmodiophora brassicae
}

\author{
Juliana C. Sodário Cruz ${ }^{1}$, Nilton Luiz de Souza ${ }^{2}$, Andreia K. Nakatani ${ }^{4}$, Daniel D. Rosa ${ }^{2}$, Marco Antonio \\ Basseto $^{2}$, Carlos Roberto Padovani ${ }^{3} \&$ Edson Luiz Furtado ${ }^{2}$
}

${ }^{1}$ APTA Pólo Centro Oeste, 17201-970, Jaú, SP, Brasil; ${ }^{2}$ Departamento de Produção Vegetal, Faculdade de Ciências Agronômicas; ${ }^{3}$ Departamento de Bioestatística, Instituto de Biociências, Universidade Estadual Paulista, 18603-970, Botucatu, SP, Brasil; ${ }^{4}$ Monsanto, 38400-174 Uberlândia, MG, Brasil

Autor para correspondência: Juliana C. Sodário Cruz, e-mail:cruzjcs@apta.sp.gov.br.

\begin{abstract}
RESUMO
Poucos estudos foram desenvolvidos no Brasil sobre a doença hérnia das crucíferas, causada por Plasmodiophora brassicae. Realizou-se testes de severidade da doença causada por diferentes populações do patógeno em espécies de brássicas (couve-flor, couvechinesa suscetível, couve-chinesa resistente, brócolis e repolho). As populações de $P$. brassicae foram obtidas de raízes de brássicas infectadas originárias de algumas regiões produtoras no Brasil. Os testes de severidade foram realizados em casa de vegetação $\left(25 \pm 2^{\circ} \mathrm{C}\right)$ mediante inoculações, no colo de cada planta com $2 \mathrm{~mL}$ da suspensão de esporos do patógeno, na concentração de $10^{7}$ esporos $\mathrm{mL}^{-1}$. As avaliações ocorreram 35 dias após a inoculação. Em laboratório foi realizada a extração de DNA dessas populações e análises de PCR-RAPD para a comparação das características genéticas. As populações obtidas nas regiões de Carandaí MG e Colombo PR mostraram-se mais agressivas, manifestando patogenicidade até mesmo em cultivar considerada resistente. Entretanto, não foi observado um padrão genético específico quanto ao local de origem das populações avaliadas, sugerindo que mesmo em locais distantes e com diferenças quanto à severidade, tais populações são geneticamente semelhantes.
\end{abstract}

Palavras chaves: hérnia das crucíferas, PCR, patógeno de solo, Brassicaceae.

ABSTRACT

Pathogenic and molecular characterization of Plasmodiophora brassicae

Few studies have been conducted with clubroot disease in Brazil, caused by Plasmodiophora brassicae. Tests on severity of disease using different populations were carried out in brassica species (cauliflower, susceptible Chinese cabbage, resistant Chinese cabbage, broccoli, and cabbage). P. brassicae populations were obtained from infected roots in several commercial production regions in Brazil. Severity tests were conducted under greenhouse conditions $\left(25 \pm 2^{\circ} \mathrm{C}\right)$ with inoculations $(2 \mathrm{~mL})$ of spore suspension at concentration of $10^{7}$ spores. $\mathrm{mL}^{-1}$, applied in the collar root of each plant. Disease evaluations were performed 35 days after inoculation. DNA extraction and PCR-RAPD analyses for these populations were conducted to compare genetic traits. The populations obtained from the regions of Carandaí MG and Colombo PR was more aggressive, and cause symptoms even in cultivars considered resistant. However, no specific genetic pattern was observed as to the place of origin or aggressiveness.

Keywords: clubroot, PCR, soilborne pathogen, Brassicaceae.

\section{INTRODUÇÃO}

Plasmodiophora brassicae Woronin é o patógeno responsável pela doença popularmente conhecida como hérnia das crucíferas (HDC), uma das mais importantes nas regiões produtoras de brássicas no mundo. Esta doença, característica de regiões de temperaturas amenas, em torno de $\pm 20^{\circ} \mathrm{C}$, vem ganhando expressão em áreas agrícolas tradicionalmente cultivadas com brássicas no Brasil. Uma vez presente no solo, as estruturas de resistência do patógeno

Parte da Tese de Doutorado do primeiro autor. Universidade Estadual Paulista. Botucatu SP. 2007. podem sobreviver por mais de 15 anos (Wallenhammar, 1996), o que dificulta seu controle.

Em decorrência da dificuldade de seu isolamento, por se tratar de um parasita obrigatório, pouco se sabe sobre seu desenvolvimento em condições brasileiras de cultivo, o que explica a existência de maior número de trabalhos que avaliam o comportamento de populações de $P$. brassicae, como os realizados por Ito et al. (1999b) e Murakami et al. (2000) no Japão, quando comparados aos que utilizam isolados monospórico, como o realizado por ManzanaresDauleux et al. (2001) na França. Alguns trabalhos relatam a existência de populações heterogêneas do patógeno em uma mesma área, podendo algumas estruturas de resistência serem patogênicas e outras não, sendo esta uma das 
maiores dificuldades metodológicas com quem trabalha com P. brassicae (Diederichsen et al., 1996). A forma mais recomendada de controle da HDC é a utilização de cultivares com maior nível de resistência, pois é considerada a maneira mais eficiente e econômica. Mas para que essa resistência a doença seja mantida, é fundamental o entendimento da diversidade do patógeno e os fatores que interferem na sua agressividade em condições ambientais brasileiras.

Pouco se sabe sobre a agressividade das populações brasileiras de $P$. brassicae, mas alguns trabalhos realizados em outros países trazem algumas importantes informações, principalmente com relação à observação de diferenças significativas existentes entre populações heterogêneas, como as obtidas na Austrália (Crute et al., 1983), Japão (Kuginuki et al., 1999) e Escócia (Jones et al., 1982a), bem como de isolados monospóricos, realizados por Somé et al. (1996) na França e Klever et al. (2001) na Alemanha. Para complementar as informações obtidas a campo sobre P. brassicae, a utilização de métodos moleculares pode permitir tanto a detecção precoce do patógeno no hospedeiro ou no solo, bem como a diferenciação de patótipos. Além disso, pode possibilitar melhor compreensão da relação entre $P$. brassicae e diferentes hospedeiros, visando o desenvolvimento de estratégias apropriadas de controle.

Parsons et al. (2003) e Faggian et al. (2003) conseguiram extrair o DNA das estruturas de repouso de P. brassicae de isolados encontrados em solos australianos, e utilizaram esse DNA extraído para análises de PCR. Desta maneira, obtiveram uma metodologia de detecção do patógeno antes do cultivo do hospedeiro. Entretanto, os autores ressaltam que a técnica não é viável quando existem baixas concentrações das estruturas de repouso no solo. Ito et al. (1999a) também demonstraram a viabilidade do uso da técnica de PCR para o estudo genético do DNA de P. brassicae, extraído de estruturas de repouso do patógeno encontrados em solos, e de estruturas presentes nos tecidos de hospedeiros (Ito et al., 1999b). Este trabalho teve como objetivo a avaliação da patogenicidade e severidade de alguns isolados (populações) brasileiros de P. brassicae, coletados a campo, bem como a caracterização molecular desses isolados, na tentativa de se obter maiores informações que possam favorecer o controle da doença e o desenvolvimento de novas cultivares resistentes.

\section{MATERIAL E MÉTODOS}

\section{Isolados de Plasmodiophora brassicae}

Raízes de brássicas apresentando sintomas de hérnias, naturalmente infectadas por $P$. brassicae, foram coletadas de áreas agrícolas brasileiras e analisadas no laboratório de Fitopatologia da Faculdade de Ciências Agronômicas, Departamento de Produção Vegetal/Defesa Fitossanitária, UNESP, Botucatu, SP, onde foram congeladas em freezer comum antes de serem utilizadas (Cruz et al., 2009). Destes materiais, onze isolados (populações) foram selecionados e catalogados conforme local, data de coleta e hospedeiro (Tabela 1).

\section{Teste de Patogenicidade}

Dois ensaios foram conduzidos nos períodos de junho a setembro (ensaio I) e agosto a outubro (ensaio II) de 2006. Para tanto, os onze isolados foram multiplicados em mudas de couve-chinesa (Brassica rapa var. pekinensis), de uma cultivar suscetível ao patógeno (Pak choi), para que suas estruturas de repouso fossem ativadas após os períodos de armazenamento em freezer. Mudas de couveflor (B. oleraceae var. botrytis), cultivar Sharon; brócolis ( $B$. oleracea L. var. italica) cultivar Ramoso Santana; repolho (B. oleracea var. capitata) cultivar Kenzan; couve-chinesa - cultivar suscetível (B. rapa var. pekinensis) Pak choi; couve-chinesa - cultivar resistente (B. rapa var. pekinensis) Komachi, com quatro semanas de semeadura foram transplantadas para vasos com capacidade de $1,7 \mathrm{~L}$, contendo solo estéril, inoculadas e irrigadas, quando necessário.

As características químicas dos solos utilizados nos ensaios I e II estão demonstradas na Tabela 2. Os ensaios foram mantidos em condições parcialmente controladas de casa de vegetação $\left( \pm 25^{\circ} \mathrm{C}\right)$, nas dependências do

TABELA 1 - Descrição dos isolados de Plasmodiophora brassicae conforme local, data e hospedeiro coletado

\begin{tabular}{llcl}
\hline \hline Número & Procedência & Data de coleta & Hospedeiro \\
\hline 1 & Carandaí (MG) & $25 / 08 / 05$ & Repolho \\
2 & Divinolândia (SP) & $21 / 07 / 03$ & Brócolis \\
3 & Piedade (SP) & $29 / 08 / 05$ & Repolho \\
4 & São José do Rio Pardo (SP) & $21 / 07 / 03$ & Brócolis \\
5 & Colombo 1 (PR) & $18 / 11 / 05$ & Couve-chinesa \\
6 & Colombo 2 (PR) & $18 / 11 / 05$ & Couve-chinesa \\
7 & Colombo 3 (PR) & $18 / 11 / 05$ & Couve-chinesa \\
8 & Colombo 4 (PR) & $18 / 11 / 05$ & Couve-chinesa \\
9 & Colombo 5 (PR) & $18 / 11 / 05$ & Couve-chinesa \\
10 & Pardinho 1 (SP) & $28 / 08 / 05$ & Rúcula \\
11 & Pardinho 2 (SP) & $19 / 01 / 06$ & Brócolis \\
\hline
\end{tabular}


Departamento de Produção Vegetal/Defesa Fitossanitária da FCA-UNESP, Botucatu (SP), conduzidos em diferentes períodos: I: 28/07/06 a 01/09/06; II: 25/09/06 a 30/10/06.

Para a inoculação, 10 gramas de raízes, mostrando sintomas típicos de hérnias foram trituradas em liquidificador, por um minuto, com $200 \mathrm{~mL}$ de água destilada. Entre as triturações dos diferentes isolados, o copo do liquidificador foi desmontado e desinfestado por lavagem em água corrente com detergente comum, depois em solução de álcool a $70 \%$, por 1 minuto, solução de hipoclorito de sódio a $2 \%$ por 1 minuto, e finalmente, enxaguado em água corrente. As suspensões obtidas foram filtradas em camadas de gaze para a retirada de fragmentos de raízes e a concentração de inóculo ajustada com o auxílio de hemacitômetro. Em seguida foram feitas inoculações no colo de cada planta, com $2 \mathrm{~mL}$ da suspensão de esporos de P. brassicae, na concentração de $10^{7}$ esporos $\mathrm{mL}^{-1}$.

Cada tratamento contou com seis repetições, onde cada repetição foi composta de um vaso com uma planta, distribuídas em blocos ao acaso. Passadas cinco semanas após a inoculação, as raízes foram lavadas e avaliadas. Para tanto foi utilizada uma escala visual de notas variando de 0 a $4(0=0 \%, 1=25 \%, 2=50 \%, 3=75 \%$ e $4=100 \%)$, conforme a porcentagem da área radicular afetada (Takahashi et al., 2005) (Figura 1). Os dados foram submetidos à análise de variância não paramétrica de Kruskal-Wallis, para o modelo com dois fatores em blocos completos, sendo os tratamentos distribuídos de forma casual, quanto ao hospedeiro e local de origem, complementada com o respectivo teste de comparações múltiplas (Zar, 1999), obtendo-se dessa maneira a mediana e semi-amplitude total da severidade da doença causada por $P$. brassicae, para cada isolado em diferentes hospedeiros de cada ensaio. Raízes dos hospedeiros que apresentaram sintomas de hérnias e nota igual ou acima de 1 (aproximadamente 25\% da área radicular afetada) foram considerados suscetíveis aos isolados testados.

\section{Extração de DNA}

O DNA dos isolados de $P$. brassicae foi obtido mediante suspensões de esporos, onde $10 \mathrm{~g}$ de raízes contendo sintomas de HDC de cada isolado foram trituradas em liquidificador, com $50 \mathrm{~mL}$ de água destilada esterilizada por 1 minuto, para que a suspensão ficasse concentrada. Posteriormente, essa suspensão foi filtrada em dez camadas

TABELA 2 - Análise química dos solos utilizados nos ensaios de severidade (I e II) de Plasmodiophora brassicae em casa de vegetação

\begin{tabular}{|c|c|c|c|c|c|c|c|c|c|c|}
\hline & $\mathrm{pH}$ & M.O. & $\mathrm{P}$ resina & $\mathrm{H}+\mathrm{Al}$ & K & $\mathrm{Ca}$ & $\mathrm{Mg}$ & SB & CTC & V \\
\hline Ensaio $^{(1)}$ & $\mathrm{CaCl}_{2}$ & $\mathrm{~g} \mathrm{dm}^{-3}$ & $\mathrm{mg} \mathrm{dm}{ }^{-3}$ & & & \multicolumn{2}{|c|}{$\mathrm{mmol}_{\mathrm{c}} \mathrm{dm}^{-3}$} & & & $\%$ \\
\hline I & $6,4^{(2)}$ & 163 & 593 & 17 & 25,5 & 109 & 50 & 184 & 201 & 91 \\
\hline II & 6,2 & 60 & 550 & 18 & 19,6 & 98 & 46 & 164 & 183 & 89 \\
\hline
\end{tabular}

(1) Ensaios conduzidos em diferentes períodos: I: 28/07/06 a 01/09/06; II: 25/09/06 a 30/10/06.

${ }^{(2)}$ Médias de três repetições.

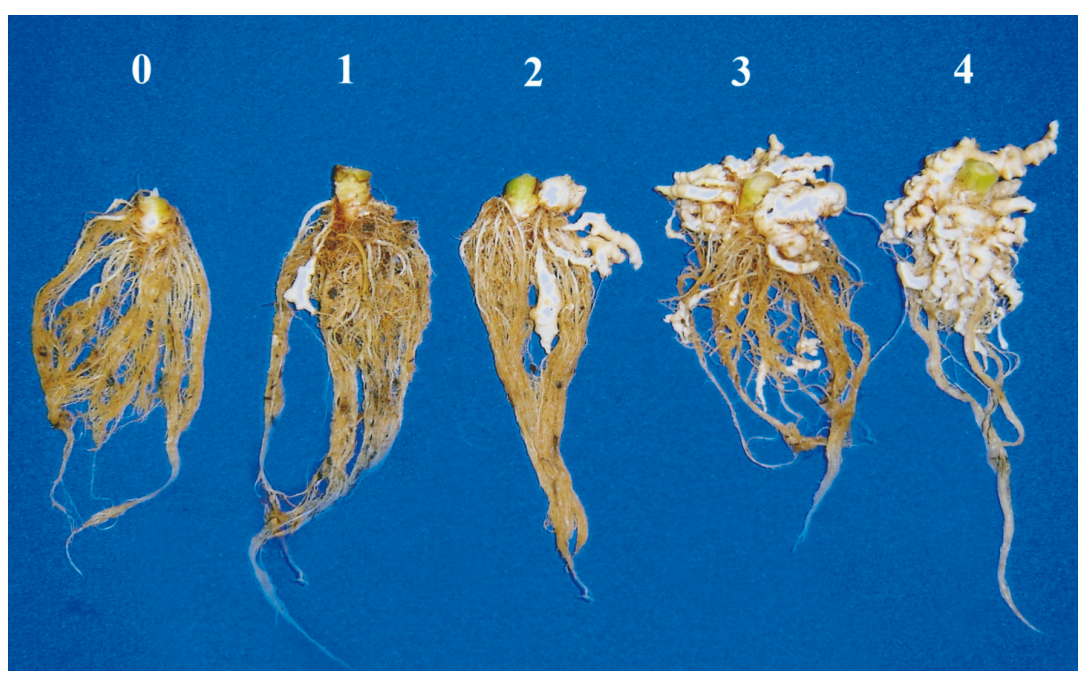

FIG. 1 - Raízes de couve-chinesa ilustrando a escala de notas utilizada na avaliação da severidade da doença causada por Plasmodiophora brassicae. $0=0 \%$ do sistema radicular afetado, $1=$ aproximadamente $25 \%$ do sistema radicular afetado, 2=aproximadamente $50 \%$ do sistema radicular afetado, $3=$ aproximadamente $75 \%$ do sistema radicular afetado e $4=100 \%$ do sistema radicular afetado. 
de gaze e acondicionada em microtubos com capacidade de $1000 \mu \mathrm{L}$, sendo então precipitada por centrifugação a $2.500 \mathrm{~g}$, durante 10 minutos, repetindo a operação quatro vezes.

O sobrenadante obtido foi descartado das amostras. Adicionou-se, em seguida, $700 \mu \mathrm{L}$ da solução I $(100 \mathrm{mM}$ $\mathrm{MgCl}_{2} ; 200 \mathrm{mM}$ Tris-HCl pH 7,4; $30 \mu \mathrm{g} \mathrm{mL}^{-1}$ DNAse) que foi incubada a $37^{\circ} \mathrm{C} \mathrm{em}$ "banho maria" por 3 horas, este passo é imprescindível para eliminação do DNA do hospedeiro, o qual poderia interferir nas análises. Em seguida, efetuouse a centrifugação por $2.500 \mathrm{~g}$, durante cinco minutos e descartou-se o sobrenadante. Os precipitados foram então ressuspendidos em $700 \mu \mathrm{L}$ da solução II (5mM EDTA; 0,5\% SDS; $10 \mathrm{mM}$ Tris- $\mathrm{HCl} \mathrm{pH} \mathrm{7,8;20} \mu \mathrm{g} \mathrm{mL}^{-1}$ de proteinase K) e incubado a $37^{\circ} \mathrm{C}$, por 30 minutos, e novamente centrifugado por $2.500 \mathrm{~g}$ durante cinco minutos sendo o sobrenadante novamente descartado (Manzanarez-Daulex et al., 2001).

O DNA foi extraído de acordo com o protocolo CTAB modificado (Doyle \& Doyle, 1990) adicionando-se 300 $\mu \mathrm{L}$ de tampão de extração ( $2 \%$ CTAB; $1,4 \mathrm{M} \mathrm{NaCl} ; 20 \mathrm{mM}$ EDTA; $100 \mathrm{mM}$ Tris-Cl pH 7,8;0,2\% mercaptoetanol) e incubado por 30 minutos, a $65^{\circ} \mathrm{C}$. O material obtido foi centrifugado a $1.100 \mathrm{~g}$ por 1 minuto, e o sobrenadante, transferido para um novo tubo.

O mesmo volume $(300 \mu \mathrm{L})$ da mistura de clorofórmio e álcool isoamílico (CIA 24:1) foi adicionado e homogeneizado em vortex, em seguida, centrifugou-se a $1.100 \mathrm{~g}$ por 2 minutos. A fase superior, aproximadamente 500 $\mu \mathrm{L}$, foi transferida para novo tubo. O DNA foi precipitado com 2/3 do volume de isopropanol gelado e mantido no gelo por 30 minutos, então submetido à centrifugação por 15 minutos, a $1.100 \mathrm{~g}$.

O sobrenadante foi descartado e, ao precipitado, adicionado $1 \mathrm{~mL}$ de álcool $70 \%$ sendo centrifugado por 10 minutos a $1.100 \mathrm{~g}$. O sobrenadante foi novamente descartado, e o precipitado permaneceu secando a temperatura ambiente, por aproximadamente 15 minutos. Depois esse precipitado foi dissolvido em $20 \mu \mathrm{L}$ de TE $(10 \mathrm{mM}$ Tris-HCl; $1 \mathrm{mM}$ EDTA) e $20 \mu \mathrm{g} \mathrm{mL}^{-1}$ de RNAse sendo, em seguida, deixado a $37^{\circ} \mathrm{C}$, por 12 horas.

\section{PCR-RAPD}

Para as reações de PCR-RAPD, segundo ManzanaresDauleux et al. (2001) modificado, o DNA de cada material foi quantificado em espectofotômetro, determinando-se a razão $\mathrm{A}_{260} / \mathrm{A}_{280}$ de todas as amostras de DNA para verificar a pureza dos ácidos nucléicos. A solução estoque de DNA foi diluída em uma concentração final de $5 \mathrm{ng} / \mu \mathrm{L}$ e estocada em freezer a $-20^{\circ} \mathrm{C}$, para que o DNA não fosse degradado, sendo posteriormente descongelada para a realização das análises de RAPD.

Em testes preliminares foram selecionados 12 primers arbitrários, obtidos da Operon Technologies Inc. (Alameda, CA, USA), sendo eles: OPB-10 (CTGCTGGGAC), OPA2 (TGCCGAGCTG), OPP-7 (GTCCATGCCA), OPP-10 (TCCCGCCTAC), OPA-3 (AGTCAGCCAC), OPG-13 (CTCTCCGCCA), OPA-7 (GAAACGGGTG), OPP-13
(GGAGTGCCTC), OPF-13 (GGCTGCAGAA), OPA-10 (GTGATCGCAG), OPA-13 (CAGCACCCAC) e OPC-16 (CACACTCCAG), que permitiram a melhor visualização do padrão de fragmentos gerados pela amplificação de DNA de P. brassicae.

Cada reação de PCR-RAPD foi composta de 7,5 $\mu \mathrm{L}$ de DNA genômico $(1 \mathrm{ng} / \mu \mathrm{L})$ e $22,5 \mu \mathrm{L}$ de solução mix de reação $[(7,45 \mu \mathrm{L}$ de água ultra pura esterilizada, 3,0 $\mu \mathrm{L}$ de solução tampão, $2,4 \mu \mathrm{L}$ de $\mathrm{dNTP}, 9,2 \mu \mathrm{L}$ de cada um dos "primers" descritos acima e 0,45 unidades de Taq polymerase (Invitrogen, Groningen, Holanda)], totalizando $30 \mu \mathrm{L}$ em tubos de PCR com capacidade de $200 \mu \mathrm{L}$. O DNA foi substituído pelo mesmo volume de água ultra pura esterilizada para servir como controle.

A amplificação foi realizada em termociclador PTC100 (MJ Research Inc., Waterown, MA), programado para iniciar o ciclo de desnaturação a $94^{\circ} \mathrm{C}$ por 30 segundos, seguido de 45 ciclos de 30 segundos a $92^{\circ} \mathrm{C}, 1$ minuto a $35^{\circ} \mathrm{C}$ e 2 minutos e 30 segundos a $72^{\circ} \mathrm{C}$, com extensão final de $72^{\circ} \mathrm{C}$ por 5 minutos. Os produtos de RAPD foram submetidos a eletroforese em gel de agarose a $1,5 \%$ e TBE $1 \mathrm{X}$, a $4 \mathrm{~V} / \mathrm{cm}$ de gel, onde foram utilizados $10 \mu \mathrm{L}$ do material da reação misturados com $5 \mu \mathrm{L}$ de tampão de carregamento $(0,25 \%$ de azul de bromofenol e $40 \%$ de sacarose) (Sambrook et al., 1987) e $5 \mu \mathrm{L}$ de marcador $1 \mathrm{~kb}$, também misturados com 5 $\mu \mathrm{L}$ de tampão de carregamento. Posteriormente, as bandas foram visualizadas e fotografadas sob luz ultravioleta em Eagle Eye II (Stratagene).

Os dados foram registrados na forma de ausência/ presença das bandas no gel. Bandas de mesmo comprimento foram consideradas como idênticas. Estes dados foram codificados na forma binária (1 para presença e 0 para ausência). A distância genética entre os isolados de $P$. brassicae foi determinada pelo coeficiente de similaridade de Nei \& Li (1979). A matriz de similaridade foi, em seguida, transformada em um dendrograma não enraizado, utilizando-se o método SAHN Clustering (Sequential Agglomerative, Hierarchical and Nested) sob procedimento UPGMA (Unweighted PairGroup Method with Arithmetic Averaging), no programa PAUP* (version 4.0b5a) (Swofford, 2002).

\section{RESULTADOS E DISCUSSÃO}

Dos onze isolados analisados, nove foram patogênicos à cultivar de couve-chinesa suscetível (Pak choi) no ensaio I, realizado no período de junho a setembro de 2006, e dois isolados não foram patogênicos, os isolados 3 (PiedadeSP) e 6 (Colombo 2-PR) (Tabela 3). No ensaio II todos os isolados foram altamente agressivos para esta cultivar, (Tabela 4). Embora o isolado 3 não tenha sido patogênico no ensaio I, no ensaio II este isolado foi patogênico para couve-flor, couve-chinesa suscetível e repolho, e o isolado 6 , somente para a cultivar de couve-chinesa suscetível neste mesmo ensaio, o que pode indicar certa preferência destes isolados para se desenvolverem em períodos que tendem a ser mais quentes do ano (setembro a outubro). 
TABELA 3 - Mediana e semi-amplitude total da severidade da doença hérnia das crucíferas em diferentes hospedeiros inoculados com isolados de Plasmodiophora brassicae. Ensaio I (28/07/06 a 01/09/06)

\begin{tabular}{lccccl}
\hline \hline \multirow{2}{*}{ Código dos isolados } & \multicolumn{5}{c}{ Hospedeiros } \\
\cline { 2 - 6 } & $\mathbf{C F}^{(\mathbf{1})}$ & $\mathbf{C C S}$ & $\mathbf{C C R}$ & $\mathbf{R E}$ & BR \\
\hline 1 & $2,0 \pm 1,5 \mathrm{bA}^{(2)}$ & $4,0 \pm 0,5 \mathrm{bB}$ & $2,0 \pm 1,0 \mathrm{bA}$ & $3,5 \pm 2,0 \mathrm{bAB}$ & $2,5 \pm 1,5 \mathrm{bA}$ \\
2 & $0,0 \pm 0,5 \mathrm{abA}$ & $2,5 \pm 2,0 \mathrm{aA}$ & $0,0 \pm 0,0 \mathrm{aA}$ & $1,0 \pm 0,5 \mathrm{abA}$ & $0,0 \pm 1,0 \mathrm{abA}$ \\
3 & $0,0 \pm 0,0 \mathrm{aA}$ & $0,0 \pm 0,0 \mathrm{aA}$ & $0,0 \pm 0,0 \mathrm{aA}$ & $0,0 \pm 0,0 \mathrm{aA}$ & $0,0 \pm 0,0 \mathrm{aA}$ \\
4 & $0,0 \pm 0,5 \mathrm{abA}$ & $2,5 \pm 2,0 \mathrm{bA}$ & $0,0 \pm 0,0 \mathrm{aA}$ & $0,0 \pm 2,0 \mathrm{abA}$ & $0,5 \pm 0,5 \mathrm{abA}$ \\
5 & $0,0 \pm 0,0 \mathrm{aA}$ & $1,5 \pm 2,0 \mathrm{abA}$ & $1,5 \pm 2,0 \mathrm{abA}$ & $2,0 \pm 2,0 \mathrm{abA}$ & $1,0 \pm 0,5 \mathrm{abA}$ \\
6 & $0,0 \pm 0,0 \mathrm{aA}$ & $0,0 \pm 0,0 \mathrm{aA}$ & $0,0 \pm 0,0 \mathrm{aA}$ & $0,0 \pm 0,5 \mathrm{abA}$ & $0,0 \pm 0,5 \mathrm{abA}$ \\
7 & $0,0 \pm 0,0 \mathrm{aA}$ & $4,0 \pm 1,5 \mathrm{bB}$ & $2,0 \pm 2,0 \mathrm{bA}$ & $2,0 \pm 0,5 \mathrm{bA}$ & $0,5 \pm 2,0 \mathrm{abA}$ \\
9 & $1,0 \pm 1,5 \mathrm{abA}$ & $4,0 \pm 1,5 \mathrm{bA}$ & $3,0 \pm 2,0 \mathrm{bA}$ & $1,5 \pm 2,0 \mathrm{abA}$ & $1,0 \pm 1,0 \mathrm{abA}$ \\
10 & $1,0 \pm 2,0 \mathrm{abA}$ & $4,0 \pm 2,0 \mathrm{bA}$ & $3,0 \pm 2,0 \mathrm{bA}$ & $1,5 \pm 2,0 \mathrm{abA}$ & $2,5 \pm 2,0 \mathrm{bA}$ \\
11 & $0,5 \pm 1,5 \mathrm{abA}$ & $2,0 \pm 1,5 \mathrm{bB}$ & $0,0 \pm 0,5 \mathrm{abA}$ & $0,0 \pm 0,5 \mathrm{abA}$ & $1,0 \pm 2,0 \mathrm{abA}$ \\
Testemunha & $0,0 \pm 0,0 \mathrm{aA}$ & $1,0 \pm 2,0 \mathrm{abA}$ & $0,0 \pm 0,0 \mathrm{aA}$ & $0,0 \pm 0,5 \mathrm{abA}$ & $0,0 \pm 0,0 \mathrm{aA}$ \\
\hline
\end{tabular}

(1) CF: couve-flor, CCS: couve-chinesa cultivar suscetível, CCR: couve-chinesa cultivar resistente, RE: repolho, BR: brócolis.

(2) Teste não paramétrico de Kruskal-Wallis $(\mathrm{p}<0,001)$, onde letras minúsculas representam as comparações de origens das populações fixados hospedeiros (coluna) e letras maiúsculas representam as comparações de hospedeiros dentro de origem (linha).

TABELA 4 - Mediana e semi-amplitude total da severidade da doença hérnia das crucíferas em diferentes hospedeiros inoculados com isolados de Plasmodiophora brassicae. Ensaio II (25/09/06 a 30/10/06)

\begin{tabular}{lccccc}
\hline \hline \multirow{2}{*}{ Código dos isolados } & \multicolumn{5}{c}{ Hospedeiros } \\
\cline { 2 - 6 } & \multicolumn{7}{c}{$\mathbf{C F}^{(\mathbf{1})}$} & $\mathbf{C C S}$ & $\mathbf{C C R}$ & $\mathbf{R E}$ & BR \\
\hline 1 & $0,0 \pm 2,0 \mathrm{aA}{ }^{(2)}$ & $2,0 \pm 2,0 \mathrm{bcA}$ & $1,0 \pm 1,5 \mathrm{abA}$ & $0,0 \pm 0,5 \mathrm{aA}$ & $0,0 \pm 0,5 \mathrm{aA}$ \\
2 & $0,0 \pm 0,5 \mathrm{aA}$ & $4,0 \pm 2,0 \mathrm{cA}$ & $0,0 \pm 0,0 \mathrm{aA}$ & $0,5 \pm 1,0 \mathrm{abA}$ & $0,0 \pm 0,5 \mathrm{aA}$ \\
3 & $1,5 \pm 2,0 \mathrm{aA}$ & $4,0 \pm 0,5 \mathrm{cB}$ & $0,0 \pm 0,0 \mathrm{aA}$ & $3,0 \pm 2,0 \mathrm{bA}$ & $0,0 \pm 2,0 \mathrm{aA}$ \\
4 & $0,5 \pm 2,0 \mathrm{aA}$ & $4,0 \pm 2,0 \mathrm{cB}$ & $0,0 \pm 0,0 \mathrm{aA}$ & $0,0 \pm 1,5 \mathrm{aA}$ & $0,0 \pm 1,0 \mathrm{aA}$ \\
6 & $0,0 \pm 0,0 \mathrm{aA}$ & $1,0 \pm 2,0 \mathrm{abA}$ & $0,0 \pm 1,0 \mathrm{aA}$ & $0,0 \pm 0,0 \mathrm{aA}$ & $0,0 \pm 0,0 \mathrm{aA}$ \\
7 & $0,0 \pm 1,0 \mathrm{aA}$ & $4,0 \pm 0,0 \mathrm{cB}$ & $0,0 \pm 0,0 \mathrm{aA}$ & $0,5 \pm 1,0 \mathrm{abA}$ & $0,0 \pm 1,0 \mathrm{aA}$ \\
9 & $0,0 \pm 1,5 \mathrm{aA}$ & $3,5 \pm 1,5 \mathrm{cB}$ & $0,5 \pm 2,0 \mathrm{abA}$ & $0,0 \pm 1,5 \mathrm{aA}$ & $0,5 \pm 1,0 \mathrm{aA}$ \\
10 & $0,0 \pm 0,5 \mathrm{aA}$ & $4,0 \pm 0,0 \mathrm{cB}$ & $1,0 \pm 2,0 \mathrm{abA}$ & $0,0 \pm 1,0 \mathrm{aA}$ & $0,0 \pm 0,5 \mathrm{aA}$ \\
11 & $0,0 \pm 2,0 \mathrm{aA}$ & $4,0 \pm 1,5 \mathrm{cB}$ & $3,0 \pm 2,0 \mathrm{bAB}$ & $0,5 \pm 1,0 \mathrm{abA}$ & $1,0 \pm 2,0 \mathrm{aA}$ \\
Testemunha & $0,5 \pm 1,0 \mathrm{aA}$ & $2,5 \pm 1,5 \mathrm{bcB}$ & $0,0 \pm 0,0 \mathrm{aA}$ & $0,5 \pm 1,5 \mathrm{abA}$ & $0,0 \pm 0,5 \mathrm{aA}$ \\
\hline
\end{tabular}

${ }^{(1)}$ CF: couve-flor, CCS: couve-chinesa cultivar suscetível, CCR: couve-chinesa cultivar resistente, RE: repolho, BR: brócolis.

(2) Teste não paramétrico de Kruskal-Wallis $(\mathrm{p}<0,001)$, onde letras minúsculas representam as comparações de origens das populações fixados hospedeiros (coluna) e letras maiúsculas representam as comparações de hospedeiros dentro de origem (linha).

Os diferentes resultados podem ser atribuídos ao efeito do ambiente e adaptação dos isolados às condições climáticas de cultivo ocorridas no ensaio II (meses de setembro a outubro de 2006), provavelmente devido ao maior comprimento do dia e intensidade luminosa encontrada nessa época do ano, quando comparado ao ensaio I. Os fatores ambientais não controlados na casa de vegetação utilizada podem ter deixado os hospedeiros mais 
propensos às infecções para esses isolados. A severidade de $P$. brassicae é resultado da interação do genótipo do hospedeiro com o genótipo do patógeno e as condições de cultivo, onde plantas altamente suscetíveis que estão em condições de cultivo adversas, podem ser infectadas por um isolado que não é altamente agressivo e desenvolverem os sintomas, reforçando o conceito clássico de doenças.

Em contraste, um hospedeiro altamente resistente requer um isolado altamente agressivo e condições de campo ótimas para o desenvolvimento do patógeno para que ocorra o desenvolvimento da doença. Esta é a possível explicação para as diferentes reações patogênicas nas duas épocas de desenvolvimento do ensaio, visto que os hospedeiros apresentaram menor desenvolvimento da doença no ensaio II, onde o clima pode ter favorecido o desenvolvimento dos hospedeiros e prejudicado o dos isolados.

O efeito contrário foi observado no ensaio I, cultivado nos meses de julho a setembro, onde a maioria dos isolados de $P$. brassicae foi mais agressiva, pois o patógeno provavelmente foi favorecido pelo ambiente de cultivo, embora o solo utilizado neste ensaio tenha apresentado maiores índices médios de matéria orgânica e cálcio que o solo utilizado no ensaio II, o que poderia ter proporcionado sua supressividade (Niwa et al., 2007).

Os isolados 1 (Carandaí-MG), 8 (Colombo 4-PR) e 9 (Colombo 5-PR) mostraram-se patogênicos para a cultivar de couve-chinesa considerada resistente (Komachi) nos dois ensaios, mostrando que esses isolados foram capazes de quebrar a resistência inicial dessa cultivar independentemente do ambiente de cultivo. Os isolados 5 (Colombo 1-PR) e 7 (Colombo 3-PR) somente foram patogênicos em condições climáticas encontradas no ensaio I. Isto mostra que não seria prudente a indicação, da referida cultivar, para o plantio na região de Colombo-PR, independentemente da época de cultivo, e para a região de Carandaí-MG, no período de inverno brasileiro, pois pressupõe-se que nestas regiões de cultivo existam isolados altamente agressivos que podem causar o desenvolvimento da HDC nessa cultivar de couvechinesa .

No ensaio I, mais isolados mostraram-se patogênicos para repolho, como por exemplo, 1, 2 5, 7, 8 e 9, diferindo dos dados obtidos no ensaio II, onde apenas os isolados 3 e 11 foram capazes de promover a formação de hérnias. $\mathrm{O}$ mesmo também foi observado para a cultivar utilizada de brócolis, no ensaio I, onde os isolados $1,5,8,9$ e 10 provocaram a formação de hérnias. Já no ensaio II, apenas o isolado 9 mostrou-se patogênico a brócolis, indicando ser altamente suscetível a esse isolado (Colombo 5-PR). Portanto esta cultivar de brócolis (Ramoso Santana) não deve ser recomendada para o cultivo na região de Colombo-PR. Os resultados mostram que de maneira geral, os isolados de Carandaí-MG e os da região de Colombo-PR apresentaram maior severidade, dentro dos ensaios desenvolvidos para os diferentes hospedeiros, quando comparados aos isolados coletados no Estado de São Paulo.

Para os demais hospedeiros, a patogenicidade dos isolados não foi uniforme, já que para couve-flor, no ensaio
I foram patogênicos os isolados 1,8 e 9 , já no ensaio II, apenas o isolado 3 causou sintomas, que não havia se mostrado patogênico no ensaio anterior. Estas variações são compreensíveis, visto que cada população pode apresentar estruturas de repouso com diferentes graus de severidade, podendo desenvolver a doença conforme as condições ambientais presentes em determinados momentos (Williams, 1966).

Algumas repetições, dentro de cada parcela para determinados isolados com menor severidade, apresentaram plantas com formação de hérnias nos ensaios I e II (Tabela 3 e 4), indicando que estes isolados podem apresentar potencial de desenvolvimento da doença, dependendo do ambiente de cultivo utilizado, como mostram os isolados: 10 para couve-flor; 4 para repolho e os 2 e 7 para brócolis no ensaio I e os isolados $1,4,6,7,9,10$ e 11 para couve-flor; 5 e 7 para couve-chinesa Komachi (resistente); 2, 4, 6, 7, 8 e 9 para repolho e os 3, 4, 6 e 7 para brócolis no ensaio II (Tabela 5).

Muitos estudos desenvolvidos com $P$. brassicae utilizaram linhas de hospedeiros diferenciadores da European Clubroot Differential (ECD) como referenciais em trabalhos similares a este. Entretanto, Kuginuki et al. (1999) comparando os hospedeiros da ECD e os utilizados por Williams (1966) em cultivares japonesas, com relação a populações de P. brassicae, verificaram que esses hospedeiros diferenciais (ECD) não classificaram claramente 36 populações japonesas quanto à patogenicidade. Esses autores relatam que os resultados dependem da pureza genética das cultivares e que o ideal, para este tipo de estudo, ainda são os materiais oriundos de isolamentos monospóricos, que apresentam maior homogeneidade genética.

Este tipo de isolamento, entretanto, pode apresentar baixa porcentagem infectiva, provavelmente em decorrência da variabilidade genética dos isolados coletados a campo, como no trabalho desenvolvido por Somé et al. (1996), que obteve aproximadamente $10 \%$ das mudas inoculadas monosporicamente com sintomas. Jones et al. (1982b) também se depararam com a mesma problemática, pois apenas três plantas de B. campestris var. pekinensis cv Granaat (suscetível) apresentaram hérnias quando inoculadas monosporicamente, considerando-se as 450 inoculadas menos de $1 \%$ de sucesso foi obtido utilizando esta técnica.

Donald et al. (2006) também observaram a interferência das condições climáticas de cultivo no desenvolvimento de sintomas em linhas diferenciadoras da ECD (European Clubroot Differential), infectadas por esporos produzidos nestes mesmos hospedeiros, na Austrália. As linhas diferenciadoras (ECD) utilizadas mostraram reações intermediárias de severidade em função das diferentes condições climáticas (luz, matéria orgânica, temperatura, $\mathrm{pH}$ ) encontradas nesse país, que diferem das condições de cultivo européias. Isto indica a necessidade de uma reformulação das linhas diferenciadoras ECD, como já relatado por Dixon (2001) e Kuginuki et al. 
(1999). Recentemente, muitos estudos têm indicado o uso de métodos moleculares para a separação de patótipos de P. brassicae, na tentativa de oferecer melhores ferramentas para o desenvolvimento de cultivares de brássicas resistentes a HDC em maior escala.

Hatakayema et al. (2006) também não utilizaram as plantas diferenciadoras de Williams (1966) e ECD, por não mostrarem resultados claros quanto à patogenicidade para isolados japoneses. Mas esses autores conseguiram fazer um agrupamento conforme o comportamento patogênico, o que também poderia ser feito para os isolados 2 e 10 deste trabalho, pois apresentaram características patogênicas semelhantes nos dois ensaios, para os mesmos hospedeiros, podendo ser considerados pertencentes a um mesmo grupo, embora tenham sido coletados em locais e em espécies diferentes de hospedeiros dentro do Estado de São Paulo.

Uma sugestão para um próximo trabalho seria a repetição dos ensaios nas mesmas épocas, porém em anos seqüentes. Entretanto, Dixon \& Robinson (1986) também observaram diferenças quanto a patogenicidade de isolados, em diferentes hospedeiros testados em quatro anos seguidos na Escócia, mesmo não ocorrendo nenhuma anormalidade climática entre esses anos. Tal resultado sugere que o mecanismo de formação de hérnias é mais influenciado pelo metabolismo hormonal do hospedeiro e, conseqüentemente, pelo desenvolvimento da planta e seu vigor.

Os padrões de fragmentos gerados pela amplificação de DNA de P. brassicae, com os "primers" OPA-02 (TGCCGAGCTG) e OPB-10 (CTGCTGGGAC), mostraram o alto grau de polimorfismo do DNA das populações de $P$. brassicae, o que era esperado, por não se tratar de isolados homogêneos (Figura 2). Mesmo com estes resultados, obteve-se $81,6 \%$ de similaridade entre as populações, (Figura 3, Tabela 6) onde observamos a formação de três grupos geneticamente similares, sendo eles: Grupo 1: isolados 1, 2, 5, 10; Grupo 2: 3 e 7 e Grupo 3: 4, 6, 8, 9 e 11. Esses isolados não apresentaram um padrão genético específico quanto ao local de origem das populações avaliadas, mostrando que, mesmo em locais distantes e com diferenças quanto à patogenicidade, tais populações são geneticamente semelhantes. Os resultados obtidos nas análises moleculares e de severidade da doença, para hospedeiros inoculados com diferentes isolados, sugerem que os isolados 2 e 10 são possivelmente originários de um mesmo patótipo, mas pertencem a grupos geneticamente diferentes.

Estes resultados mostram que populações (isolados) coletadas de um mesmo local, em períodos e hospedeiros diferentes, como os isolados 10 e 11, são geneticamente diferentes, provavelmente resultante dos cruzamentos entre os possíveis distintos patótipos existentes dentro de uma mesma área e população de $P$. brassicae (Jones et al., 1982b). E isso nos leva a crer que hospedeiros resistentes, a uma determinada população de uma região, pode ter sua resistência alterada em regiõesdecultivopróximas, poiscadapopulaçãoéevidentemente variável quanto à patogenicidade, indicando a necessidade de estudos mais detalhados para que essa variabilidade patogênica seja contornada e cultivares de brássicas com maior grau de resistência sejam desenvolvidas.

A alta variabilidade e não correlação entre os resultados obtidos em casa de vegetação e os moleculares

TABELA 5 - Patogenicidade de isolados de Plasmodiophora brassicae, em diferentes hospedeiros e épocas de ensaio (I e II).

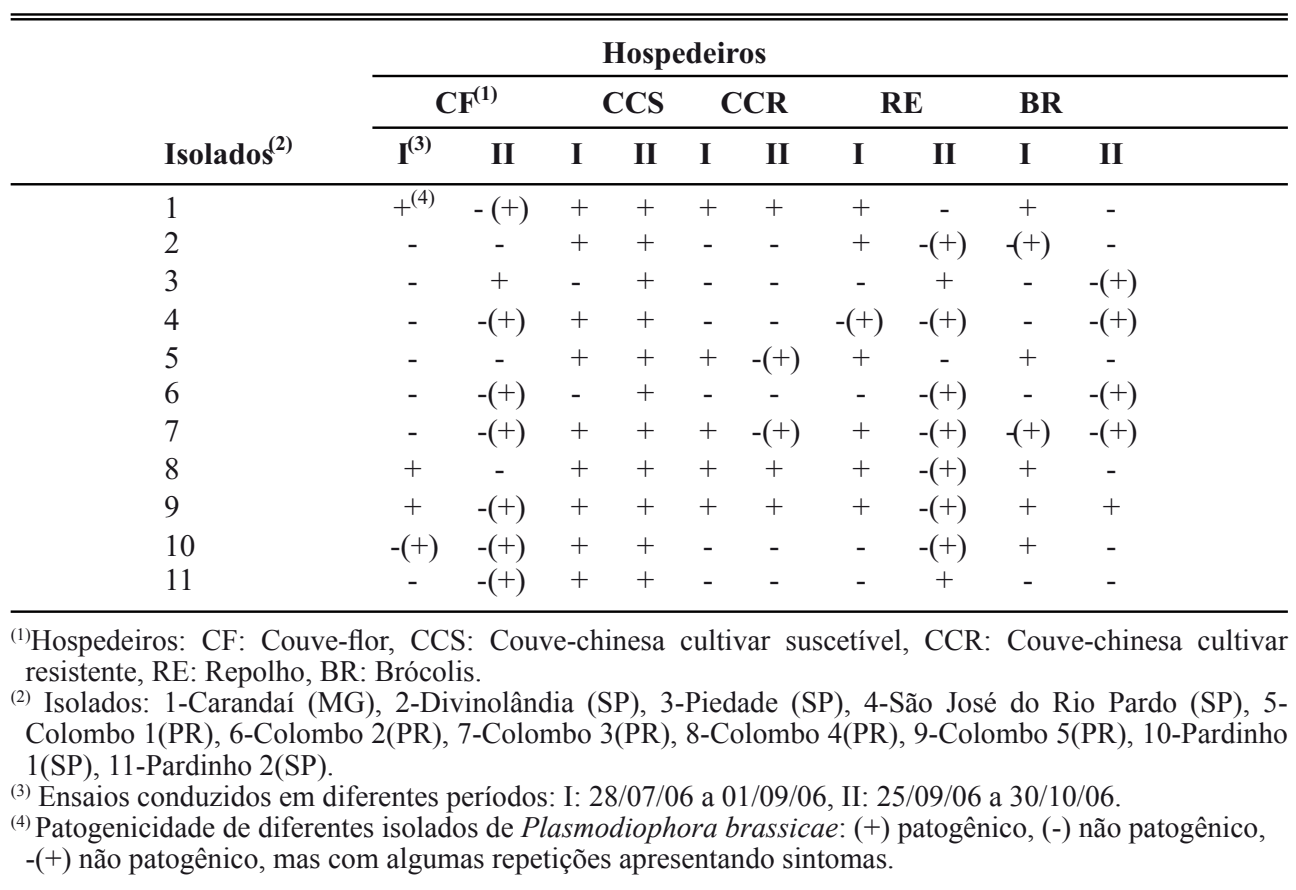



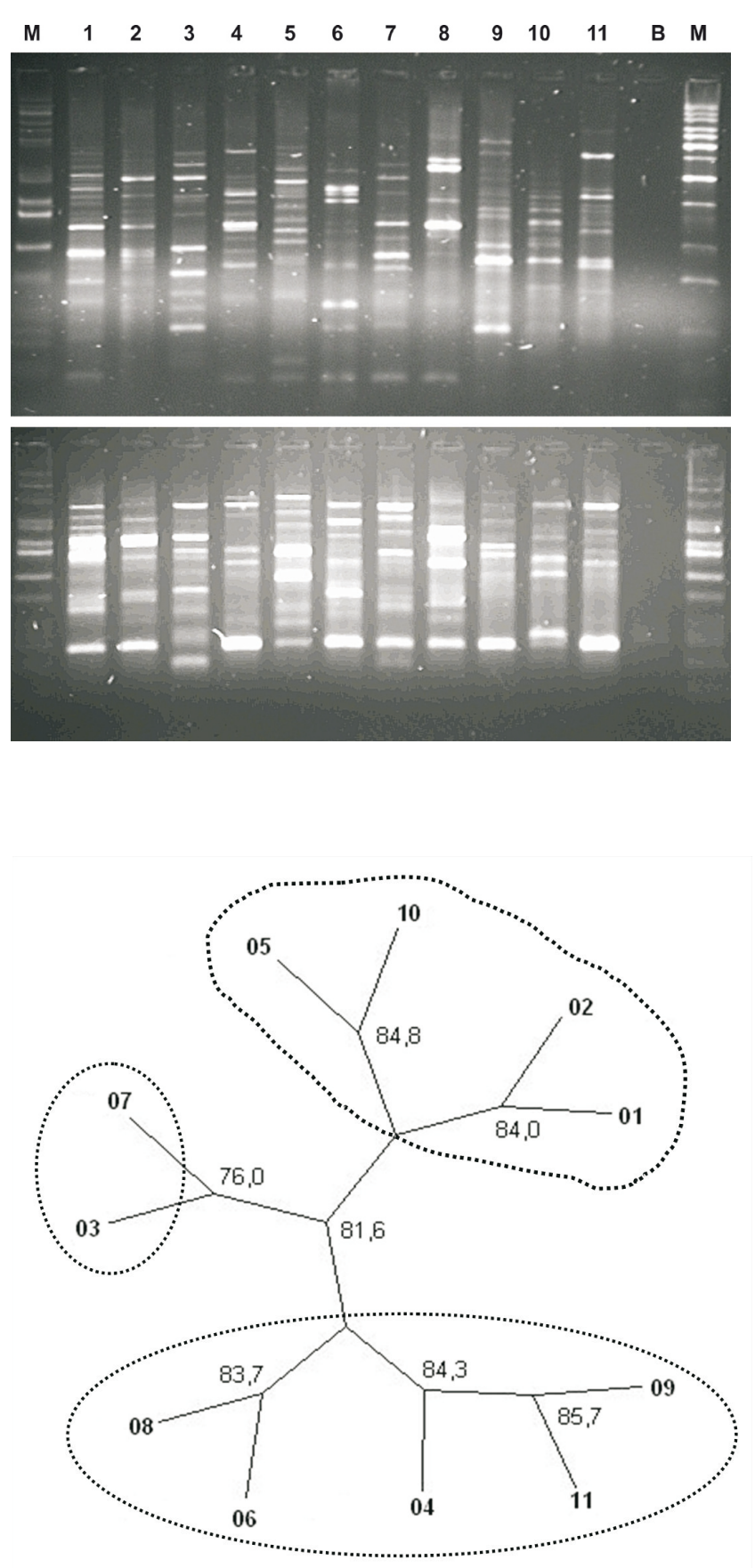

sugere a realização de estudos futuros quanto a adaptação de análises moleculares mais refinadas para a análise de isolados brasileiros, como por exemplo, os desenvolvidos por Kageyama et al. (2003) que utilizaram a região ITS do DNA de populações coletadas de solos japoneses, e primers específicos para estudos similares ao desenvolvido. Faggian et al. (1999) também utilizaram a região ITS do DNA ribossomal (DNAr) e a técnica de nested PCR, por se tratar de uma região mais preservada.

Manzanares-Dauleux et al. (2001) também conseguiram, através da análise do DNA de nove populações de Plasmodiophora brassicae e de trinta e sete isolados
FIG. 2 - Padrão de bandas de polimorfismo de DNA amplificado ao acaso (RAPD), com os "primers" A. OPA2 e B. OPB10, de isolados de Plasmodiophora brassicae causadores da hérnia das crucíferas. Isolados: 1- Carandaí (MG), 2-Divinolândia (SP), 3-Piedade (SP), 4-São José do Rio Pardo (SP), 5-Colombo 1 (PR), 6-Colombo 2 (PR), 7-Colombo 3 (PR), 8-Colombo 4 (PR), 9-Colombo 5 (PR), 10-Pardinho 1 (SP), 11-Pardinho 2 (SP), $\mathrm{M}=$ marcador molecular $1 \mathrm{~kb}$ (Amershan) e $\mathrm{B}=$ água ultra pura esterilizada.

FIG.3 - Dendrograma não enraizado de isolados de Plasmodiophora brassicae, gerada pelo agrupamento UPGMA. Os valores presentes nos nós internos representam a similaridade genética dos isolados.

monospóricos, com o uso de primers específicos e PCR RAPD, diferenciar oito patótipos franceses. Outro fator que deve ser levado em consideração é a pequena quantidade de DNA coletado das estruturas de resistência de P. brassicae, que acabam por mascarar os padrões de fragmento de polimorfismo. Cao et al. (2007), entretanto, relatam que o patógeno pode ser detectado em tecidos do hospedeiro após 3 dias da inoculação, por meio de PCR, mesmo não ocorrendo a formação de hérnias antes de 24 dias, mostrando a viabilidade desta técnica para detecções precoces, e sua utilização em análises rotineiras de laboratório.

Parsons et al. (2003) descrevem que a técnica 
TABELA 6 - Similaridade genética entre os isolados de Plasmodiophora brassicae gerada a partir de bandas polimórficas obtidas por RAPD. Valores baseados no coeficiente de similaridade Nei \& Li (1979)

\begin{tabular}{|c|c|c|c|c|c|c|c|c|c|c|}
\hline \multirow[t]{2}{*}{ Isolados ${ }^{(1)}$} & \multicolumn{10}{|c|}{ Isolados $^{(1)}$} \\
\hline & 1 & 2 & 3 & 4 & 5 & 6 & 7 & 8 & 9 & 10 \\
\hline 2 & 84,0 & & & & & & & & & \\
\hline 3 & 78,4 & 76,0 & & & & & & & & \\
\hline 4 & 82,6 & 79,8 & 72,1 & & & & & & & \\
\hline 5 & 84,4 & 83,3 & 74,4 & 76,7 & & & & & & \\
\hline 6 & 81,9 & 79,2 & 78,5 & 81,8 & 76,4 & & & & & \\
\hline 7 & 83,6 & 82,1 & 76,0 & 82,6 & 72,5 & 79,5 & & & & \\
\hline 8 & 83,5 & 82,2 & 77,0 & 80,5 & 83,7 & 83,7 & 76,6 & & & \\
\hline 9 & 81,2 & 77,1 & 72,5 & 84,1 & 77,8 & 78,0 & 74,0 & 81,2 & & \\
\hline 10 & 83,1 & 83,6 & 74,4 & 78,5 & 84,8 & 72,2 & 77,2 & 77,9 & 84,5 & \\
\hline 11 & 82,6 & 79,1 & 77,0 & 84,5 & 79,4 & 82,8 & 82,6 & 80,7 & 85,7 & 84,0 \\
\hline
\end{tabular}

${ }^{(1)}$ Isolados:1-Carandaí (MG), 2-Divinolândia (SP), 3-Piedade (SP), 4-São José do Rio Pardo (SP), 5-Colombo 1(PR), 6-Colombo 2(PR), 7-Colombo 3(PR), 8-Colombo 4(PR), 9-Colombo 5(PR), 10-Pardinho 1(SP) e 11-Pardinho 2(SP).

de PCR é capaz de detectar estruturas de repouso de $P$. brassicae viáveis e não viáveis de solo, mas que, para os não viáveis, a detecção decai com o passar do tempo de vida destas estruturas, o que também deve ser levado em consideração, pois somente interessa a detecção de materiais viáveis, o que ainda não é possível. Esses trabalhos reforçam o potencial de uso desta técnica, bem como a necessidade de aprimoramento de trabalhos voltados para a caracterização de possíveis patótipos de $P$. brassicae no Brasil, utilizando PCR e espécies de brássicas cultivadas no País, juntamente com algumas linhas diferenciadoras de ECD, para que informações mais conclusivas sejam obtidas, visando o controle da doença.

\section{AGRADECIMENTOS}

À empresa Sakata Seed Sudamérica Ltda, pela doação de sementes de brássicas e alguns isolados de Plasmodiophora brassicae.

\section{REFERÊNCIAS BIBLIOGRÁFICAS}

Cao T, Tewari J, Strelkov SE (2007) Molecular detection of Plasmodiophora brassicae, causal agent of clubrot of crucifers, in plant and soil. Plant Disease 91:80-87.

Crute TR, Phelps K, Barner A, Buczacki ST, Crisp P (1983) The relationship between genotypes of three Brassica species and collections of Plasmodiophora brassicae. Plant Pathology 32:405420 .
Cruz JCS, Souza NL, Furtado EL, Padovani CR (2009) Preservação do inóculo de Plasmodiophora brassicae utilizando o método de congelamento. Summa Phytopathologica (no prelo).

Diederichsen E, Wagenblatt B, Schallehns V, Deppe U, Sacristán MD (1996) Transfer of clubroot resistance from resynthesised Brassica napus into oilseed rape - Identification of race-especific interactions with Plasmodiophora brassicae. Acta Horticulturae 407:423-430.

Dixon GR (2001) International clubroot working group-clubroot, Cruciferae Newsletter, Domaine de la Motte 23:91-92.

Dixon GR, Robinson DL (1986) The susceptibility of Brassica oleracea cultivars to Plasmodiophora brassicae (clubroot). Plant Pathology 35:101-107.

Donald EC, Cross SJ, Lawrence JM, Porter IJ (2006) Pathotypes of Plasmodiophora brassicae, the cause of clubroot, in Australia. Annals of Applied Biology 148:239-244.

Doyle JJ, Doyle JL (1990) Isolation of plant DNA from fresh tissue. Focus 12:13-15.

Faggian R, Bulman SR, Lawrie AC, Porter IJ (1999) Specific polymerase reaction primers for the detection of Plasmodiophora brassicae in soil and water. Phytopathology 89:392-397.

Faggian R, Parsons S, Donald EC, Lawrie AC, Porter IJ (2003) Molecular detection and quantification of $P$. brassicae. Proceedings, 8. International Congress of Plant Pathology, Christchurch, New Zeland. p. 82.

Hatakayema K, Fujimura M, Ishida M, Suzuki T, Sato T (2006) Classification of pathogenicity of Plasmodiophora brassicae field isolates in Japan based on resistance of F1 cultivars of Chinese cabbage (Brassica pekinensis L.) to clubroot. Acta Horticulturae 706:317-322.

Ito S, Maehara T, Maruno E, Tanaka S, Kameya-Iwaki M, Kishi F (1999a) Development of a PCR-based assay for the detection of Plasmodiophora brassicae in soil. Journal of Phytopathology 147:83-88. 
Ito S, Ichinose H, Yanagi C, Tanaka S, Kameya-Iwaki M, Fishi F (1999b) Identification of an in planta-induced mRNA of Plasmodiophora brassicae. Journal of Phytopathology 147:79-82.

Jones DR, Ingram DS, Dixon GR (1982a) Factors affecting tests for differential pathogenicity in populations of Plasmodiophora brassicae. Plant Pathology 31:229-238.

Jones DR, Ingram DS, Dixon GR (1982b) Characterization of isolates derived from single resting spores of Plasmodiophora brassicae and studies of their interaction. Plant Pathology 31:239246.

Kageyama K, Komatsu T, Haruhisa S (2003) Refined PCR protocol for detection of plant pathogens in soil. Journal of General Plant Pathology 69:153-160.

Klever A, Luerben H, GrafH, Siemens J (2001) Restriction fragment length polymorphism markers to characterize Plasmodiophora brassicae single-spore isolates with different virulence patterns. Journal of Phytopathology 149:121-127.

Kuginuki Y, Yoshikawa H, Hirai M (1999) Variation in virulence of Plasmodiophora brassicae in Japan tested with clubroot-resistant cultivars of chinese cabbage (Brassica rapa L. spp. pekinensis). European Journal of Plant Pathology 105:327-332.

Manzanarez-Daulex MJ, Divaret I, Baron F, Thomas G (2001) Assessment of biological and molecular variability between and within field isolates of Plasmodiophora brassicae. Plant Pathology 50:165-173.

Murakami H, Tsushima S, Akimoto T, Murakami K, Goto I, Sishido Y (2000) Effects of growing leafy daikon (Raphanus sativus) on populations of Plasmodiophora brassicae (clubroot). Plant Pathology 49:584-589.

Nei M, Li WH (1979) Mathematical model for studying genetic variation in terms of restriction endonucleases. Proceedings of the
National Academy of Sciences of the USA. 76:5269-5273.

Niwa R, Kumei T, Nomura Y, Yoshida S, Osaki M, Ezawa T (2007) Increase in soil $\mathrm{pH}$ due Ca-rich organic matter application causes suppression of the clubroot disease of crucifers. Soil Biology \& Biochemistry 39:778-785.

Parsons S, Faggian R, Lawrie AC (2003) The relationship between PCR and the viability of Plasmodiophora brassicae resting spores. Proceedings, 8. International Congress of Plant Pathology, Christchurch, New Zeland. p. 83.

Sambrook J, Fritsch EF, Maniats T (1987) Molecular Cloning: A Laboratory Manual Cold Spring Harbor, NY, USA. Cold Spring Harbor Laboratory Press.

Somé A, Manzanares MJ, Baron F, Thomas G (1996) Variation for virulence on Brassica napus amongst Plasmodiophora brassicae collections from France and derived single-spore isolates. Plant Pathology 45:432-439.

Swofford DL, Paup* (2002) Phylogenetic analysis using parsimony (*and other methods), version 4.0b5a. Sunderland. Sinauer Associates.

Takahashi LM, Cebrian IT, Souza NL (2005) Inoculação de Plasmodiophora brassicae agente causal da "hérnia das crucíferas". Summa Phytopathologica 31:S16. (Resumo)

Wallenhammar Ac (1996) Prevalence of Plasmodiophora brassicae in a spring oilseed growing area in central Sweden and factors influencing soil infestation level. Plant Pathology 45:710-719.

Williams PH (1996) A system for the determination of races of Plasmodiophora brassicae that infect cabbage and rutabaga. Phytopathology 56:624-625.

Zar JH (1999) Biostatistical analysis. 4. ${ }^{\text {th }}$ Ed. New Jersey. Prentice Hall.

Recebido 14 Abril 2008 - Aceito 12 Dezembro 2008 - TPP 8040 Editor Associado: Nilceu R.X. Nazareno 